\title{
New records of Diaphanosoma pseudodubium Korovchinsky, 2000 (Crustacea: Cladocera: Sididae) from Eastern Siberia, with description of males of this species
}

\section{Новые данные о Diaphanosoma pseudodubium Korovchinsky, 2000 (Crustacea: Cladocera: Sididae) из Восточной Сибири \\ с описанием самцов данного вида}

\author{
N.M. Korovchinsky ${ }^{1}$, O.P. Dubovskaya ${ }^{2,3}$ \\ Н.М. Коровчинский ${ }^{1}$, О.П. Аубовскаяя ${ }^{2,3}$
}

\footnotetext{
${ }^{1}$ A.N. Severtsov Institute of Ecology and Evolution, Leninsky prospect 33, Moscow 119071, Russia. E-mail: nmkor@yandex.ru ${ }^{1}$ Институт проблем экологии и эволюции им.А.Н. Северцова РАН, Ленинский проспект, 33, Москва 119071, Россия. ${ }^{2}$ Institute of Biophysics of Siberian Branch of Russian Academy of Science, Akademgorodok 50/50, Krasnoyarsk 660036, Russia. E-mail: dubovskaya@ibp.krasn.ru

${ }^{2}$ Институт биофизики Сибирского отделения Российской академии наук, Академгоодок 50/50, Красноярск 660036, Россия.

${ }^{3}$ Siberian Federal University, Svobodny avenue, 79, Krasnoyarsk 660041, Russia.

${ }^{3}$ Сибирский федеральный университет, Свободный проспект,79, Красноярск 660041, Россия.
}

KEY WORDS: Diaphanosoma pseudodubium, description of male, Eastern Siberia, geographic distribution. КЛЮЧЕВЫЕ СЛОВА: Diaphanosoma pseudodubium, описание самца, Восточная Сибирь, географическое распространение.

ABSTRACT. The males of rare species Diaphanosoma pseudodubium Korovchinsky, 2000 are described for the first time from the basins of Vilyui River (Central Yakutia) and the Lower Yenisei River (Krasnoyarsk region). This is supplemented by the description of some morphological structures of females, which were previously missed. Based on known localities it may be suggested that range of the species embraces the vast area of the Eastern Siberia and the Far East.

РЕЗЮМЕ. Впервые описываются самцы редкого вида Diaphanosoma pseudodubium Korovchinsky, 2000, найденные в бассейнах реки Вилюй (Центральная Якутия) и Нижнего Енисея. Эти сведения дополняются описанием некоторых морфологических структур самок данного вида, которые были ранее пропущены. Основываясь на данных об известных местонахождениях, можно предполагать, что ареал вида охватывает обширную территорию Восточной Сибири и Дальнего Востока.

\section{Introduction}

The rare species Diaphanosoma pseudodubium Korovchinsky, 2000 was found for the first time in two lakes, Dabanda and Pir, in the Lower Amur River system [Korovchinsky, 2000]. Since then, this species was recorded from two water bodies of the Middle and Lower Zeya River (tributary of the Amur River) [Korovchinsky, Sheveleva, 2009]. In both areas only par- thenogenetic females were collected and described.

Further collecting efforts yielded in encountering of the species yet in two additional localities in Eastern Siberia situated far apart from those noted above and related to different river basins, namely the Lena River in Central Yakutia and the Lower Yenisei River (in the latter one, it was preliminary identified as $D$. cf. macrophthalma Korovchinsky et Mirabdullaev, 1995, see Dubovskaya et al. [2010]). In each region, both females and males were found which allows describing the latter for the first time. Besides this, the encountered new material let us possible to investigate some additional morphological structures (thoracic limbs, etc), morphological variability, and make more precise conclusion on geographic distribution of the species under consideration.

Abbreviations: ad - adult parthenogenetic female, gam - gamogenethic female, I - large two-segmented setulated seta on distal corner of gnathobases of tl Itl V, juv - juvenile females, J - modified thorn-like naked, hooked seta on distal corner of gnathobases of $t l$ III-tl V, $n$ - number of filtering setae of endopodite and gnathobase of thoracic limbs, $\mathrm{p}$ - not-setulated seta on proximal corner of gnathobases of $\mathrm{tl}$ II- $\mathrm{tl} \mathrm{V}, \mathrm{tl}$ I...tl VI - thoracic limbs of first... sixth pairs.

Study area, material and methods

Specimens of $D$. pseudodubium were taken from the following localities: 


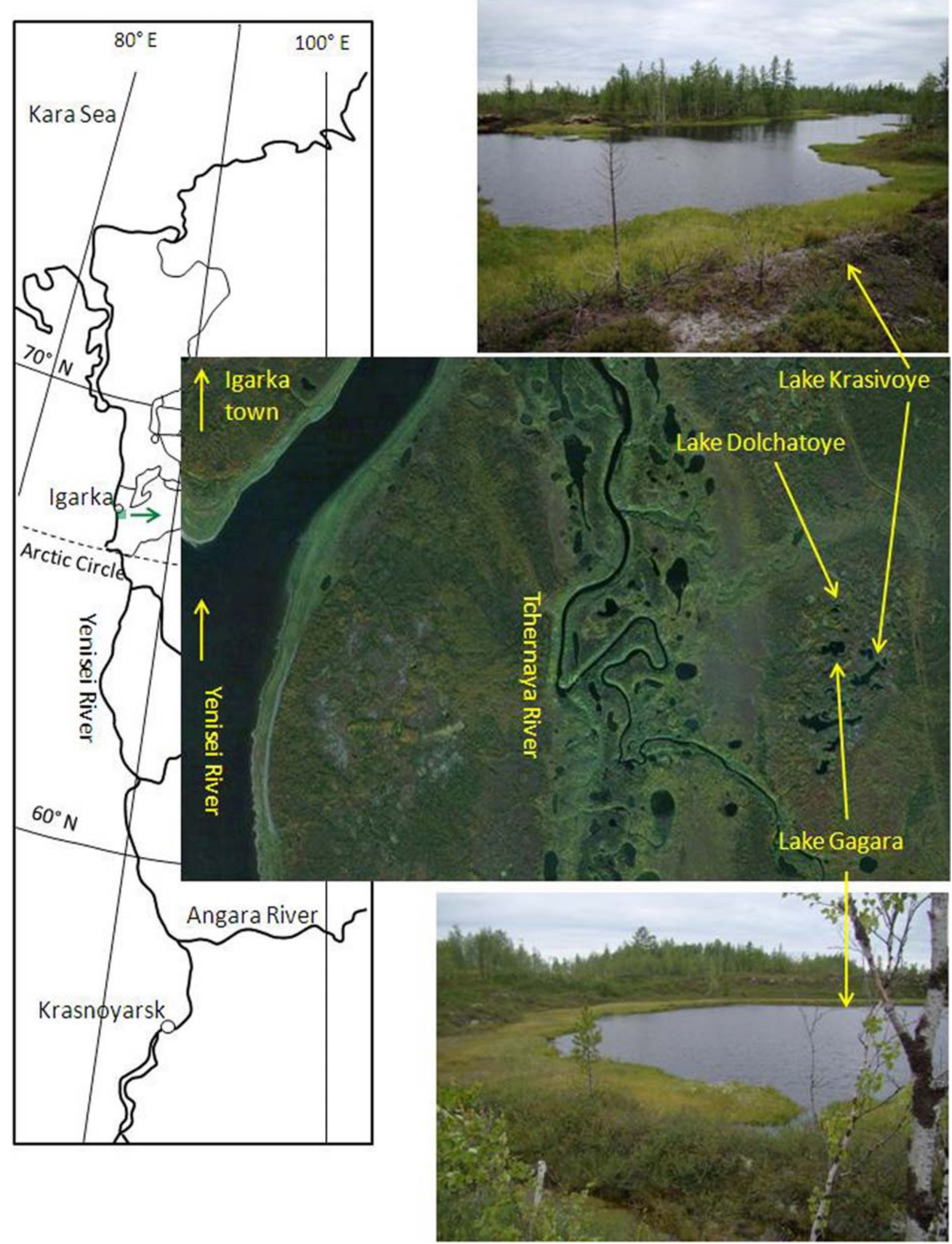

Fig.1. The locality and map of the area studied.

Рис.1. Местоположение и карта района исследований. 
Table 1. Some characteristics of two studied lakes in the Chernaya River basin (the Lower Yenisei River). Таблица 1. Некоторые характеристики двух исследованных озер в бассейне реки Черной (Нижний Енисей).

\begin{tabular}{|l|l|l|}
\hline Characteristics & \multicolumn{1}{l}{ Lake Gagara } & Lake Krasivoye \\
Altitude, m a.s.1. & $67^{\circ} 24^{\prime} 19^{\prime \prime} \mathrm{N}, 86^{\circ} 45^{\prime} 12^{\prime \prime} \mathrm{E}$ & $67^{\circ} 24^{\prime} 15^{\prime \prime} \mathrm{N}, 86^{\circ} 45^{\prime} 36^{\prime \prime} \mathrm{E}$ \\
Water surface area, $\mathrm{m}^{2}$ & 30 & 30 \\
$\mathrm{pH}(14-18.07 .2004)$ & 10008 & 10666 \\
$\mathrm{~T},{ }^{\circ} \mathrm{C}$ & $5.3-5.6$ & $5.5-6.2$ \\
& $23.5-23.8(14.07 .2004)$ & $20.5(18.07 .2004)$ \\
$\mathrm{Ca}, \mu \mathrm{g} \mathrm{L}{ }^{-1}(2004)$ & $14.3(22.07 .2011)$ & $13.8(22.07 .2011)$ \\
$\mathrm{Mg}, \mu \mathrm{g} \mathrm{L}{ }^{-1}(2004)$ & $13.8-13.7(22-25.08 .2013)$ & $1200-2300$ \\
$\mathrm{Fe}, \mu \mathrm{g} \mathrm{L}{ }^{-1}(2004)$ & $500-800$ & $600-1000$ \\
$\mathrm{Mn}, \mu \mathrm{g} \mathrm{L}{ }^{-1}(2004)$ & $30-72$ & $145-179$ \\
\hline
\end{tabular}

Krasnoyarsk region, vicinity of Igarka Town, basin of the Chernaya River, the Lower Yenisei River basin, coll. O.P. Dubovskaya: 1) Lake Gagara, 25.08.2013, 1 ad, 2) Lake Krasivoye, 22-25.08.2013, 12 ad, 5 gam, 3 males.

Central Yakutia: River Vilyui, kurya $4 \mathrm{~km}$ below Vilyuisk Town, August 2008, coll. I.G. Sobakina, 1 ad, 1 juv, 1 male.

In Krasnoyarsk region, individuals of $D$. pseudodubium were found in small lakes of the Chernaya River basin which is situated beyond the Arctic Circle in Lower basin of the Yenisei River (Fig.1). The Chernaya River is a small river which flows into the Yenisei River from the right valley slightly upstream the Igarka Town. The region, referring to vegetation zone of northern taiga, has acutely continental climate and is underlined by permafrost [Angaro-Yeniseiskiy region..., 1973]. Catchment area of the Chernaya River and its lakes is boggy and their waters are characterized by brownish color, rather high iron concentrations and rather low $\mathrm{pH}$ values (Table 1). Mineralization of surface waters is low with dominating $\mathrm{HCO}_{3}$ among anions and $\mathrm{Ca}$ among cations [Angaro-Yeniseiskiy region..., 1973]. The studied lakes are small and shallow and situate in peat bog flat (Table 1).

In $2004, D$. pseudodubium was found only in one of three studied lakes, Lake Krasivoye [Dubovskaya et al., 2010], in 2011, in two lakes, Lake Krasivoye and Lake Dolchatoye, and in 2013, also in two lakes, Lake Krasivoye and Lake Gagara (Dolchatoye was not sampled) (Fig.1). Zooplankton community of Krasivoye in 2004 was dominated by copepods Heterocope appen- diculata (Sars, 1863) (47 and 3\% of total zooplankton abundance on stations 1 and 2, respectively), Mesocyclops leuckarti (Claus, 1857) (14 and 9\%), and Neutrodiaptomus (Mariaediaptomus) pachypoditus (Rylov, 1925) (2 and 2\%), cladocerans Ceriodaphnia pulchella Sars, 1862 (14 and 2\%), Streblocerus serricaudatus (Fischer, 1849) (4 and 10\%) and colonies of rotifers Conochilus unicornis Rousselet, 1892 (6 and 64\%). In 2011 and 2013, lakes with D. pseudodubium were dominated by Calanoida, which nauplii composed 19 and $84 \%$ of total zooplankton in lakes Krasivoye and Dolchatoye, respectively, $N$. pachypoditus (mainly adults) -18 and $1 \%$, and $H$. appendiculata (copepodits and adults) -18 and $1 \%$. Bosmina longirostris (O.F. Müller, 1785) (14 and 4\%), Bosmina (Eubosmina) cf. longispina Leydig, 1860 (12 and $0 \%$ ), and Holopedium gibberum Zaddach, 1855 (4 and 0,1\%) dominated among cladocerans and C. unicornis among rotifers ( 9 and $4 \%$ ). In all samples, fraction of D. pseudodubium was not higher than $1 \%$ of total zooplankton. Similar low maximum abundance (1-2\%) was observed in copepods Eucyclops denticulatus (Graeter, 1903), cladocerans Simocephalus expinosus (De Geer, 1778), Scapholeberis mucronata (O.F. Müller, 1776), Ophryoxus gracilis kolymensis Smirnov, 1992, Chydorus cf. sphaericus (O.F. Müller, 1776), and rotifers Lecane constricta (Murray, 1939) and Ploesoma lenticulare Herrick, 1895. In 2013, Limnosida frontosa Sars, 1862 in Lake Krasivoye, Lathonura rectirostris (O.F. Müller, 1785), and Asplanchna herricki Guerne, 1888 in Lake Gagara might be added to the list of scanty species. 


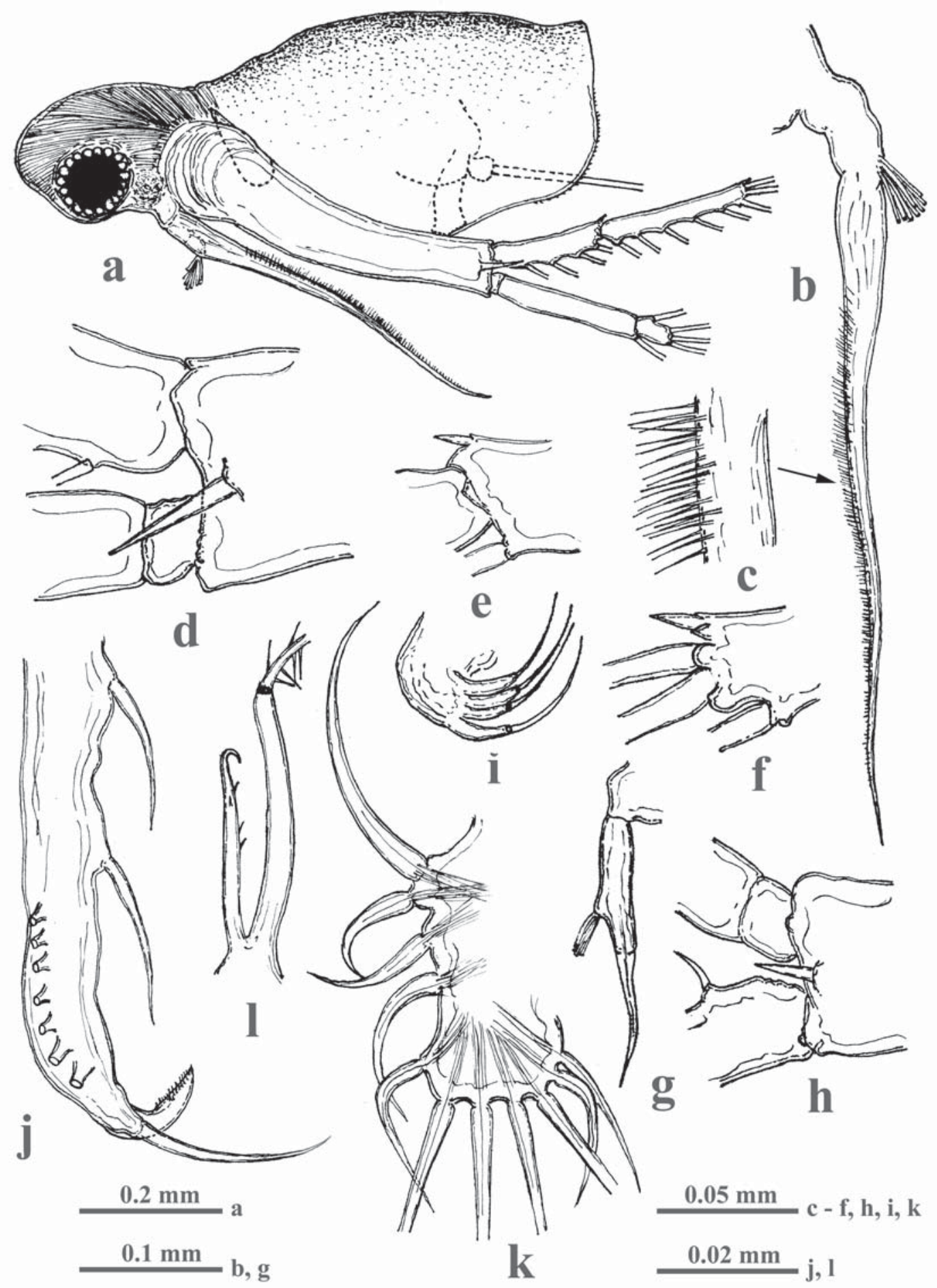

Fig. 2.Diaphanosoma pseudodubium (Lake Krasivoye, Krasnoyarsk region) (female $-\mathrm{e}, \mathrm{f}, \mathrm{i}, \mathrm{k}$, male $-\mathrm{a}-\mathrm{d}, \mathrm{g}, \mathrm{h}-\mathrm{j}, \mathrm{l}$ ): a - male, general lateral view, $\mathrm{b}$ - antennule, $\mathrm{c}$ - part of antennule with its armament, $\mathrm{d}$ - basipodital distal outer end with large thorn, $\mathrm{e}$ - distal end of proximal segment of upper antennal branch, $\mathrm{f}$ - distal end of distal segment of upper antennal branch, $\mathrm{g}$ - antennule of juvenile male, $\mathrm{h}$ - basipodital distal outer end of juvenile male, $\mathrm{i}$ - maxillula $(\mathrm{mx} \mathrm{I}), \mathrm{j}$ - distal end of endopodite of tl I, $\mathrm{k}$ - exopodite of tl IV, 1 - modified setae of distal end of gnathobase of tl IV.

Рис. 2. Diaphanosoma pseudodubium (озеро Красивое, Красноярский край) (самка - e, f, i, k, самец - a-d, g, h-j, 1): a самец, общий вид сбоку, $\mathrm{b}$ - антеннула, с - часть антеннулы с вооружением, $\mathrm{d}$ - дистальный конец базиподита с крупным шипом, е - дистальный конец проксимального членика верхней ветви антенн, $\mathrm{f}$ - дистальный конец дистального членика верхней ветви антенн, g — антеннула ювенильного самца, $\mathrm{h}$ - дистальный конец базиподита ювенильного самца, $\mathrm{i}$ - максиллула, $\mathrm{j}$ - дистальный конец эндоподита торакальной конечности первой пары, $\mathrm{k}$ - экзоподит торакальной конечности четвертой пары, 1 - модифицированные щетинки на дистальном конце гнатобазы торакальной конечности четвертой пары. 


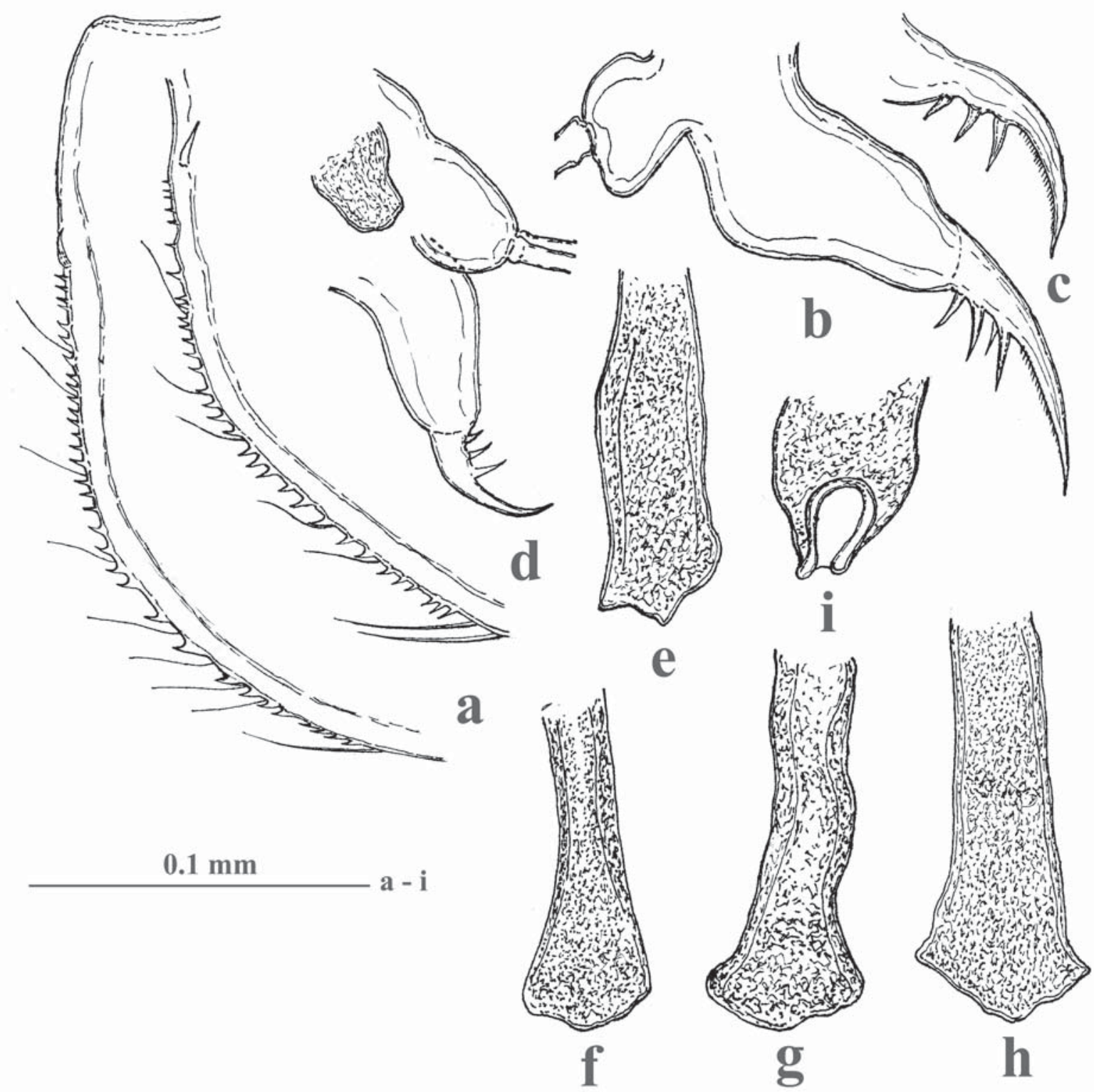

Fig. 3.Diaphanosoma pseudodubium (Lake Krasivoye, Krasnoyarsk region) (a-c - female, $\mathrm{d}-\mathrm{i}-$ male): a - armament of posteroventral valve margin, $\mathrm{b}$ - postabdomen, lateral view, $\mathrm{c}$ - postabdominal claws, $\mathrm{d}$ - postabdomen of juvenile male, $\mathrm{e}-\mathrm{h}$ - copulatory appendages, $\mathrm{i}$ - distal opening of copulatory appendage.

Рис. 3. Diaphanosoma pseudodubium (озеро Красивое, Красноярский край) (a-c - самка, d-i - самец): а-вооружение задненижнего края створок, $\mathrm{b}$ - постабдомен с боковой стороны, c - коготки постабдомена, $\mathrm{d}$ - постабдомен ювенильного самца, $\mathrm{e}-$ $\mathrm{h}$ - копулятивные придатки, - дистальное отверстие копулятивного придатка.

Latitude, longitude and altitude were determined near the station 1, using an eTrex Vista HCx GPS (Garmine) navigator; lake areas were calculated using large-scale map from Google Earth and ImageJ1.46 software; $\mathrm{pH}$ were measured by pHep2 (Hanna Instruments, U.S.A.) and temperature by Long-StemThermometer (F/C, 8, Cole-Parmer). Total concentrations of metals were measured by atomic absorption spectroscopy using spectrometers AAS-1N (Carl Zeiss) for $\mathrm{Ca}, \mathrm{Mg}$ and AAS KVANT-2A (KORTEK Ltd., Russia) for $\mathrm{Fe}, \mathrm{Mn}$ and other metals in water samples collected in pre-cleaned $250-500 \mathrm{ml}$ bottles from the surface layer of lakes.

Zooplankton samples were taken in near shore zone of lakes, using vertical and horizontal hauls with Juday plankton net (mesh size $80 \mu \mathrm{m}$, mouth diameter $25 \mathrm{~cm}$ ). The samples were fixed in $4 \%$ formaldehyde solution.

Specimens were examined under the dissecting microscope Lomo MBS-10 and compound microscope Olympus SX-41 with camera lucida. Body and body parts measurements were made according to scheme shown in Korovchinsky [2004]. In the present investi- 


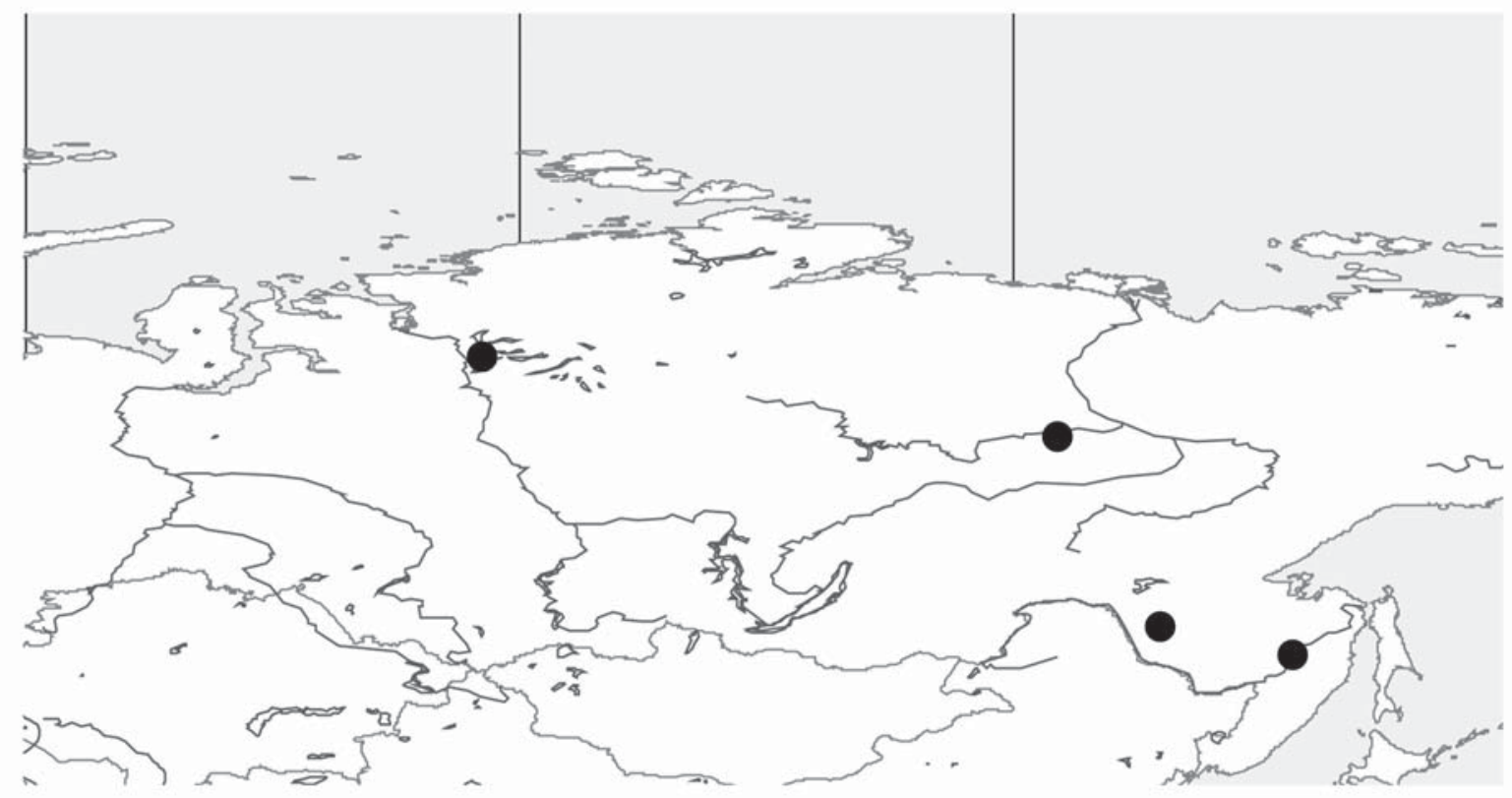

Fig. 4. Known localities of Diaphanosoma pseudodubium in Eastern Siberia and in the Far East.

Рис. 4. Известные местонахождения Diaphanosoma pseudodubium в Восточной Сибири и на Дальнем Востоке.

gation, both females and males of $D$. pseudodubium were investigated but in the former ones mostly the previously undescribed structures were analyzed.

\section{Description}

Diaphanosoma pseudodubium Korovchinsky, 2000 Figs $1-4$.

Korovchinsky, 2000: 84-87, Figs. 50-60, 2004: 291-293, Fig. 104; Korovchinsky, Sheveleva, 2009: 296-298, Fig. 6, 1-7.

Structure and armament of thoracic limbs are shown in Table 2.

Parthenogenetic females with characteristic features of the species - large head with protruding dorsal part and large eye situated antero-ventrally (10.5-14.5\% of body length), very long swimming antennae (78.9-92.5\% of body length) with characteristic apical denticles on proximal and distal segments of upper branch (Fig. 2e, f). Maxillules (mx I) with four setulated setae (Fig. 2i). Exopodites of tl IItl $\mathrm{V}$ are comparatively short and bear only three-four lateral setae (Fig. 2k). Endopodites are not segmented and look like a single whole bearing numerous filtering setae. Proximal corner of gnathobases of tl III-tl $\mathrm{V}$ bears long two-segmented seta and short hooked seta near it (Fig. 21). Shell valves with 25-31 denticled on postero-ventral margin, diminishing in size dorsally, and some thin setules between them (Fig. 3a). One large inner thorn near posterior margin of each valve. Postabdomen of specific rectangular shape with massive terminal claws, bearing rather short bas- al spines (Fig. 3c). Some females had one or two oval eggs in brood pouch $(0.22-0.23 \times 0.14 \mathrm{~mm})$. Body length $0.75-0.99 \mathrm{~mm}$.

Juvenile parthenogenetic females with fewer setae on distal segment of upper antennal branch (7) and only a rudiment of proximalmost eight seta and fewer denticles on postero-ventral valve margin (24-25). Body length $0.66-0.72 \mathrm{~mm}$.

Gamogenetic females do not differ from parthenogenetic ones in all diagnostic features but antero-dorsal part of their shell has a specifically yellowish-brown color which may indicates its heightened sclerotization. They had no resting eggs in brood pouches. Body length $0.85-1.04 \mathrm{~mm}$.

Males with long antennules (62.7-65.3\% of body length), bearing numerous thin hairs along their distal part (Fig. 2a-c). Swimming antennae with long sharp spine on basipodital distal outer end (Fig. 2d). Thoracic limbs of first pair (tl I) with large apical hook, bearing small denticles on its inner side, long naked seta near it, and two naked setae above them (Fig. 2j). Copulatory appendages large and widened funnellyshaped distally with quite variable distal margin (Fig. $3 \mathrm{e}-\mathrm{i}$ ). Postabdomen and claws as in females but one specimen had an additional basal spine on one postabdominal claw (Fig. 3b) which probably represents malformation. Body length $0.78-0.82 \mathrm{~mm}$.

Juvenile male possesses short antennules (26.3\% of body length) (Fig. 2g), shorter distal spine of antennal basipodite (Fig. 2h), and fewer setae on proximal and distal segments of upper antennal branch (3 and 7 , respectively). Denticles on postero-ventral margin of 
Table 2. Structure and armament of thoracic limbs of females of Diaphanosoma pseudodubium (Lake Krasivoye, Krasnoyarsk region) (about abbreviations see above). Таблица 2. Структура и вооружение торакальных конечностей самок Diaphanosoma pseudodubium (озеро Красивое, Красноярский край) (относительно сокращений см. выше).

\begin{tabular}{|c|c|c|c|c|}
\hline Limb pairs & $\begin{array}{c}\text { Exopodite } \\
\text { (apical + lateral setae) }\end{array}$ & Endopodite & Gnathobase & Epipodite \\
\hline I & $5+5$ & $n 41+1$ & $n 6+\mathrm{I}$ & + \\
II & $7+4$ & $n 42+2$ & $(n 21-23+\mathrm{p})+\mathrm{I}$ & + \\
III & $7+4$ & $n 42+2$ & $(n 22+\mathrm{p})+\mathrm{I}+\mathrm{J}$ & + \\
IV & $7+4$ & $n 33+2$ & $(n 22+\mathrm{p})+\mathrm{I}+\mathrm{J}$ & + \\
V & $6+3$ & $n 26+2$ & $2+\mathrm{p})+\mathrm{I}+\mathrm{J}$ & + \\
VI & $5+1$ & $7+$ one thorn & $2+$ three thorns & + \\
\hline
\end{tabular}

valves are less numerous $(\sim 12)$, hooks on tl $\mathrm{I}$ and copulatory appendages are rudimentary (Fig. 3d).

REMARKS. Studied population of the species from Lake Krasivoye probably was at stage of the beginning of gamogenetic reproduction. For this reason, the gamogenetic individuals were comparatively few and gamogenetic females yet lacked resting eggs in their brood pouches.

Specimens of $D$. pseudodubium from Yakutia were found co-occurring with females of $D$. cf. amurensis Korovchinsky et Sheveleva, the more definite identification of which needs presence of males [see Korovchinsky \& Sheveleva, 2009].

\section{Discussion}

In their morphological characteristics, the studied specimens of $D$. pseudodubium from the Lower Yenisei River and Lena River basins are closer to those from the Lower Amur River [see Korovchinsky, 2000] than to specimens from the Zeya River [see Korovchinsky \& Sheveleva, 2009] in having rather numerous denticles on postero-vental valve margins and postabdomen of a characteristic rectangular shape. Thus, the latter ones stay morphologically far apart from the representatives of all other known populations of the species, but the available material is not sufficient to make a conclusion on taxonomic significance of differences under consideration.

In three known localities (two in the Zeya River basin and one in the Viluyi River), D. pseudodubiumwas found together with $D$. amurensis (or $D$. cf. amurensis). On the whole, these species are morphologically quite different but at the same time the copulatory appendages of their males appear to be rather similar.

Until recently, the geographical distributional pattern of D. pseudodubium was uncertain. Initially, when the species was known only in the Lower Amur River [Korovchinsky, 2000], it was suggested that it has predominantly southern range. New findings of the spe- cies in the Viluyi River and especially in lakes of the Lower Yenisei River basin undoubtedly confirm new assumption about its wide distribution all over the Eastern Siberia [see Kotov et al., 2011] up to its Subarctic regions (up to $67.5^{\circ} \mathrm{N}$; this species was not found in more northern localities of the studied western side of Putorana Plateau) (Fig. 4). This suggests the mostly northern distribution of the species in Eastern Eurasia at which the Amur River basin probably represents the southern limit of its range.

ACKNOWLEDGMENTS. The work was partly supported by Russian Foundation for Basic Research (grants \# 1105-00246-a for OPD and \# 12-04-00207-a for NMK). We thank A.V. Ageev, L.A. Glushchenko, and I.V. Zuev for fieldwork assistance.

\section{References}

[Angaro-Yeniseyskiy region]. 1973. / A.P. Muranov (red.). Resursy poverkhnosnyh vod SSSR. Leningrad: Gidrometeoizdat. T.16. 724 pp. [in Russian].

Dubovskaya O.P., Kotov A.A., Korovchinsky N.M., Smirnov N.N., Sinev A.Yu. 2010. Zooplankton of lakes in the spurs of the Putorana Plateau and adjacent territories (north of Krasnoyarsk Krai) // Contem. Probl. Ecology. Vol.3. P.401-434.

Korovchinsky N.M. 2000. Redescription of Diaphanosoma dubium Manuilova, 1964 (Branchiopoda: Ctenopoda: Sididae), and description of a new, related species // Hydrobiologia. Vol.441. P.73-92.

Korovchinsky N.M. 2004. [Cladocera Ctenopoda of the world fauna (morphology, systematics, ecology, zoogeography)]. Moscow: KMK Scientific press. 410 pp. [in Russian]

Korovchinsky N.M., Sheveleva N.G. 2009. [One new species and one rare species of the genus Diaphanosoma Fischer 1850 (Crustacea, Cladocera, Sididae) from the Amur River basin] // Zool. Zhurn. Vol.88. P.289-299 [in Russian, with English summary].

Kotov A.A., Korovchinsky N.M., SinevA.Yu., Smirnov N.N. 2011. [Cladocera (Crustacea, Branchiopoda) of the Zeya River Basin (Amur Basin, Russian Federation). 3. Systematic-faunistical and zoogeographic analysis] // Zool. Zhurn. Vol.90. P.402411 [in Russian, with English summary].

Responsible editor K.G. Mikhailov 